\title{
Pseudonocardia mongoliensis sp. nov. and Pseudonocardia khuvsgulensis sp. nov., isolated from soil
}

Correspondence

Ismet Ara

ismetara@yahoo.com
The genus Pseudonocardia, originally proposed by Henssen (1957) for mycolateless nocardioform actinomycetes with a type IV cell wall, includes organisms characterized by the presence of meso-diaminopimelic acid and the sugars arabinose and galactose (Lechevalier \& Lechevalier, 1980); the major menaquinone is MK- $8\left(\mathrm{H}_{4}\right)$ and the DNA G $+\mathrm{C}$ content is $68-79 \mathrm{~mol} \%$. Pseudonocardia strains form vegetative and aerial mycelium with spore chains produced by acropetal budding or fragmentation. The description of the genus has been emended repeatedly based on both chemotaxonomic and morphological variations (Henssen \& Schäfer, 1971; Warwick et al., 1994; McVeigh et al., 1994; Reichert et al., 1998; Huang et al., 2002; Park et al., 2008).

†Present address: Department of Botany and Microbiology, College of Science, King Saud University (KSU), Post Box 22452, Riyadh 11495, Saudi Arabia.

The GenBank/EMBL/DDBJ accession numbers for the 16S rRNA gene sequences of strains MN08-A0270 ${ }^{\top}$ and MN08-A0297 ${ }^{\top}$ are AB521671 and AB521672, respectively.
On the basis of the lack of mycolic acids and the presence of cell-wall type IV, the genera Amycolata (Lechevalier et al., 1986) and Pseudoamycolata (Akimov et al., 1989) were also proposed for some nocardioform actinomycetes. However, the two genera were found to have chemotaxonomic properties similar to those of the genus Pseudonocardia (Kothe et al., 1989; Takeuchi et al., 1992) and were subsequently incorporated in the genus Pseudonocardia on the basis of the 16S rRNA gene sequence analysis (Warwick et al., 1994; McVeigh et al., 1994). Subsequently, members of the genus Actinobispora (Jiang et al., 1991) were also transferred to the genus Pseudonocardia based on identification using specific PCR primers and reanalysis of $16 \mathrm{~S}$ rRNA gene sequences and the menaquinones of their type species (Huang et al., 2002). At the time of writing, the genus Pseudonocardia encompassed 34 species (including Pseudonocardia spinosa Henssen and Schäfer 1971) with validly published names listed by Huang et al. (2002), Lee et al. (2000, 2001, 2002, 2004), Kämpfer \& Kroppenstedt (2004), Gu et al. (2006), Liu et al. (2006), Mahendra \& 
Alvarez-Cohen (2005), Qin et al. (2008, 2010), Park et al. (2008), Chen et al. (2009), Schäfer et al. (2009), Duangmal et al. (2009) and Sakiyama et al. (2010). Strains of the genus have been isolated from various environmental samples, such as active sludge soils, including those polluted by chemical compounds (Lee et al., 2004; Kämpfer \& Kroppenstedt, 2004; Mahendra \& Alvarez-Cohen, 2005; Liu et al., 2006; Kämpfer et al., 2006; Park et al., 2008), and plant samples, including stems, leaves, root nodules, tree bark, compost and Chinese medicinal plants (Evtushenko et al., 1989; Reichert et al., 1998; Gu et al., 2006; Chen et al., 2009).

In the course of our research on new actinobacterial sources in Mongolia (Ara et al., 2010a, b), strains MN08-A0270 ${ }^{\mathrm{T}}$ and MN08-A0297 ${ }^{\mathrm{T}}$ were isolated from soil collected from the area around Khuvsgul Lake, Khuvsgul province. Polyphasic taxonomic analysis demonstrated that the strains represent two novel species of the genus Pseudonocardia.

Soil samples were dried at room temperature for 5-7 days and then inoculated using the rehydration-centrifugation method (Hayakawa et al., 2000) on humic acid-vitamin agar (Hayakawa \& Nonomura, 1987) containing trimethoprim $\left(20 \mathrm{mg} \mathrm{l}^{-1}\right)$ and nalidixic acid $\left(10 \mathrm{mg} \mathrm{l}^{-1}\right)$. Following isolation, colonies were picked and strains designated MN08$\mathrm{A} 0270^{\mathrm{T}}$ and $\mathrm{MN} 08-\mathrm{A} 0297^{\mathrm{T}}$ were purified by repeated streaking on yeast extract-soluble starch medium (YS medium; 2 g yeast extract, $10 \mathrm{~g}$ soluble starch and $15 \mathrm{~g}$ agar $\mathrm{l}^{-1}, \mathrm{pH} 7.3$ ) and Bennett's agar plates $(0.1 \%$ yeast extract, $0.1 \%$ beef extract, $0.2 \% \mathrm{NZ}$ amine type A, $1.0 \%$ maltose monohydrate and $1.5 \%$ agar; pH 7.3) after incubation for about 3-4 weeks at $28{ }^{\circ} \mathrm{C}$. Purified strains $\mathrm{MN} 08-\mathrm{A} 0270^{\mathrm{T}}$ and $\mathrm{MN} 08-\mathrm{A} 0297^{\mathrm{T}}$ were maintained on YS slants at $4{ }^{\circ} \mathrm{C}$ and as hyphal fragments and spore suspensions in $20 \%(\mathrm{v} / \mathrm{v})$ glycerol at $-80{ }^{\circ} \mathrm{C}$.

The strains were grown on ISP media 2-7 (Shirling \& Gottlieb, 1966), Bennett's agar and YS medium after incubation at $28{ }^{\circ} \mathrm{C}$ for 3 weeks and cultural characteristics were observed (Table 1). The colour of the substrate hyphae was determined from the reverse side as described by Shirling \& Gottlieb (1966). Cell morphology was observed under a light microscope and by scanning electron microscopy. Light microscope observation of cells suspended in phosphate buffer $(\mathrm{pH} 7.0,1 \mathrm{mM})$ was used to tested for spore motility (Sakiyama et al., 2010). For scanning electron microscopy, agar blocks containing the organisms (cultivated on water agar medium for 21 days at $28{ }^{\circ} \mathrm{C}$ ) were fixed with the vapour of $1 \%$ osmium tetroxide and dried samples were sputter-coated and viewed with a scanning electron microscope (Tamura et al., 1994).

Strains MN08-A0270 ${ }^{\mathrm{T}}$ and MN08-A0297 ${ }^{\mathrm{T}}$ had morphological properties typical of the genus Pseudonocardia. The aerial mycelium was white and the substrate mycelium was pale yellow to yellowish brown on different agar media (Table 1). No diffusible pigment was produced. Typical pseudonocardia-type acropetal budding growth of aerial hyphae and spore chains were observed on water agar medium in both strains (Fig. 1). Spore chains were borne at the ends of branched aerial hyphae, and the spore surface was smooth.
Strain MN08-A0270 ${ }^{\mathrm{T}}$ showed very slow growth; colonies become visible after approximately 1 week of incubation and showed moderate to good growth on ISP 2, ISP 3, ISP 6, Bennett's agar and YS agar (Table 1). Growth of strain MN08$\mathrm{A} 0297^{\mathrm{T}}$ was relatively fast compared with strain MN08$\mathrm{A} 0270^{\mathrm{T}}$ and the former strain showed good growth on most of the agar media tested (Table 1). Strains MN08-A0270 ${ }^{\mathrm{T}}$ and MN08-A0297 ${ }^{\mathrm{T}}$ and reference strain Pseudonocardia thermophila NBRC $15559^{\mathrm{T}}$ could be differentiated by growth intensity, substrate mycelium colour and production of aerial mycelium on different agar media (Table 1).

Physiological and biochemical characteristics of strains MN08-A0270 ${ }^{\mathrm{T}}$ and MN08-A0297 ${ }^{\mathrm{T}}$ and the phylogenetically closely related type strain $P$. thermophila NBRC $15559^{\mathrm{T}}$ were tested after incubation at $28{ }^{\circ} \mathrm{C}$ for 3 weeks. Growth was tested at $4,10,15,20,25,28,30,37,40,45$ and $50{ }^{\circ} \mathrm{C}$ on YS agar medium. The ability of the strains to grow at $\mathrm{pH} 5.0$ 10.0 (at intervals of $1.0 \mathrm{pH}$ unit) and $0-8 \%(\mathrm{w} / \mathrm{v}) \mathrm{NaCl}$ (at intervals of $1.0 \%$ ) was examined by using YS agar as the basal medium. Media and procedures used for determination of physiological features were those described by Shirling \& Gottlieb (1966). For the nitrate reduction test, ISP 8 medium (full strength) (Gordon \& Mihm, 1957) was used. Decomposition of urea was determined on Christensen's urea agar containing 2.0\% urea (Gordon et al., 1974). Degradation of casein and other compounds (final concentration $0.5 \%$ ) was determined using YS medium as the modified basal medium (Gordon et al., 1974). Catalase activity was detected by dropping $3 \% \mathrm{H}_{2} \mathrm{O}_{2}$ onto well-developed colonies on agar plates and observing any gas bubbles produced. Other biochemical analyses were performed using modified methods of Kloos et al. (1974) and by using the API Coryne commercial biochemical test kit (bioMérieux) according to the manufacturer's instructions. Constitutive enzymic activities were tested using the API ZYM test kit (bioMérieux) according to the manufacturer's instructions (Humble et al., 1977). Detailed and differential results are given in the species descriptions and in Table 2. Each strain showed a characteristic pattern with the API ZYM test system (Table 2). Strain MN08-A0270 ${ }^{\mathrm{T}}$ could be differentiated from both strain MN08-A0297 ${ }^{\mathrm{T}}$ and $P$. thermophila NBRC $15559^{\mathrm{T}}$ by several agar-based and traditional biochemical tests, tolerance of $\mathrm{NaCl}$, growth temperature, growth $\mathrm{pH}$ and API ZYM test kit results (Table 2). In the API ZYM test strip, strains $\mathrm{MN} 08-\mathrm{A} 0270^{\mathrm{T}}$ and MN08-A0297 ${ }^{\mathrm{T}}$ were both positive for esterase $\left(\mathrm{C}_{4}\right)$, esterase lipase $\left(\mathrm{C}_{8}\right)$, leucine arylamidase, $\alpha$-glucosidase and $\beta$ glucosidase, negative for $N$-acetyl- $\beta$-glucosaminidase and $\alpha$-fucosidase and weakly positive for lipase $\left(\mathrm{C}_{14}\right)$ and naphthol-AS-BI-phosphohydrolase (Table 2).

Genomic DNA was extracted and purified as described by Marmur (1961) and Saito \& Miura (1963), but with a slight modification: after lysis, we used $20 \%$ SDS and proteinase $\mathrm{K}\left(50 \mu \mathrm{l}, 4 \mathrm{mg} \mathrm{ml}^{-1}\right.$; Nacalai Tesque) to denature proteins and phenol/chloroform/isoamyl alcohol ( $25: 24: 1$, by vol.) to remove denatured proteins. 16S rRNA gene sequences were analysed as described by Tamura \& Hatano (2001). 
Table 1. Cultural characteristics of strains $\mathrm{MNO8}-\mathrm{A} 0270^{\top}$ and $\mathrm{MN} 08-\mathrm{A} 0297^{\top}$ and $P$. thermophila NBRC $15559^{\top}$

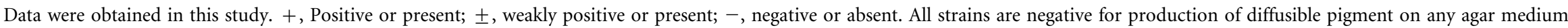

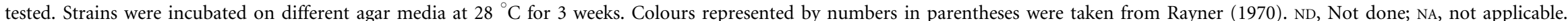
Characteristics highlighted in bold are particularly useful for differentiation of the three strains.

\begin{tabular}{|c|c|c|c|c|c|c|c|c|c|}
\hline \multirow{2}{*}{$\begin{array}{l}\text { Agar } \\
\text { medium }\end{array}$} & \multicolumn{3}{|c|}{ MN08-A0270 $^{T}$} & \multicolumn{3}{|c|}{ MN07-A0297 ${ }^{\mathrm{T}}$} & \multicolumn{3}{|c|}{ P. thermophila NBRC $15559^{\mathrm{T}}$} \\
\hline & Growth & Substrate mycelium & $\begin{array}{c}\text { Aerial } \\
\text { mycelium }\end{array}$ & Growth & Substrate mycelium & $\begin{array}{c}\text { Aerial } \\
\text { mycelium }\end{array}$ & Growth & Substrate mycelium & $\begin{array}{c}\text { Aerial } \\
\text { mycelium }\end{array}$ \\
\hline Bennett's & Good & $\begin{array}{l}\text { Hazel }(88) \text {, light to moderate } \\
\text { yellowish brown }\end{array}$ & - & Good & Honey (64), moderate yellow & + & Good & Luteus (12), vivid yellow & + \\
\hline Yeast-starch & Good & Buff (45), pale yellow & - & Good & Buff (45), pale yellow & + & Good & $\begin{array}{l}\text { Pale luteus (11), light } \\
\text { yellow }\end{array}$ & + \\
\hline Water & Poor & Colourless & - & Moderate & White to colourless & \pm & No growth & NA & NA \\
\hline ISP 2 & Good & Honey (64), moderate yellow & - & Good & Honey (64), moderate yellow & - & Good & $\begin{array}{l}\text { Fawn (87), moderate } \\
\text { brown }\end{array}$ & + \\
\hline ISP 3 & Moderate & Buff (45), pale yellow & \pm & ND & $\mathrm{ND}$ & ND & Moderate & Buff (45), pale yellow & + \\
\hline ISP 4 & ND & ND & ND & Good & Buff (45), pale yellow & + & Moderate & Buff (45), pale yellow & + \\
\hline ISP 5 & Poor & Colourless & - & Good & Honey (64), moderate yellow & \pm & Moderate & Buff (45), pale yellow & \pm \\
\hline ISP 6 & Moderate & $\begin{array}{l}\text { Hazel }(88) \text {, light to moderate } \\
\text { yellowish brown }\end{array}$ & - & Good & Honey (64), moderate yellow & - & Good & $\begin{array}{l}\text { Fawn }(87) \text {, moderate } \\
\text { brown }\end{array}$ & + \\
\hline ISP 7 & Poor & Colourless & - & Good & $\begin{array}{l}\text { Hazel }(88) \text {, light to moderate } \\
\text { yellowish brown }\end{array}$ & + & Moderate & Buff (45), pale yellow & + \\
\hline
\end{tabular}



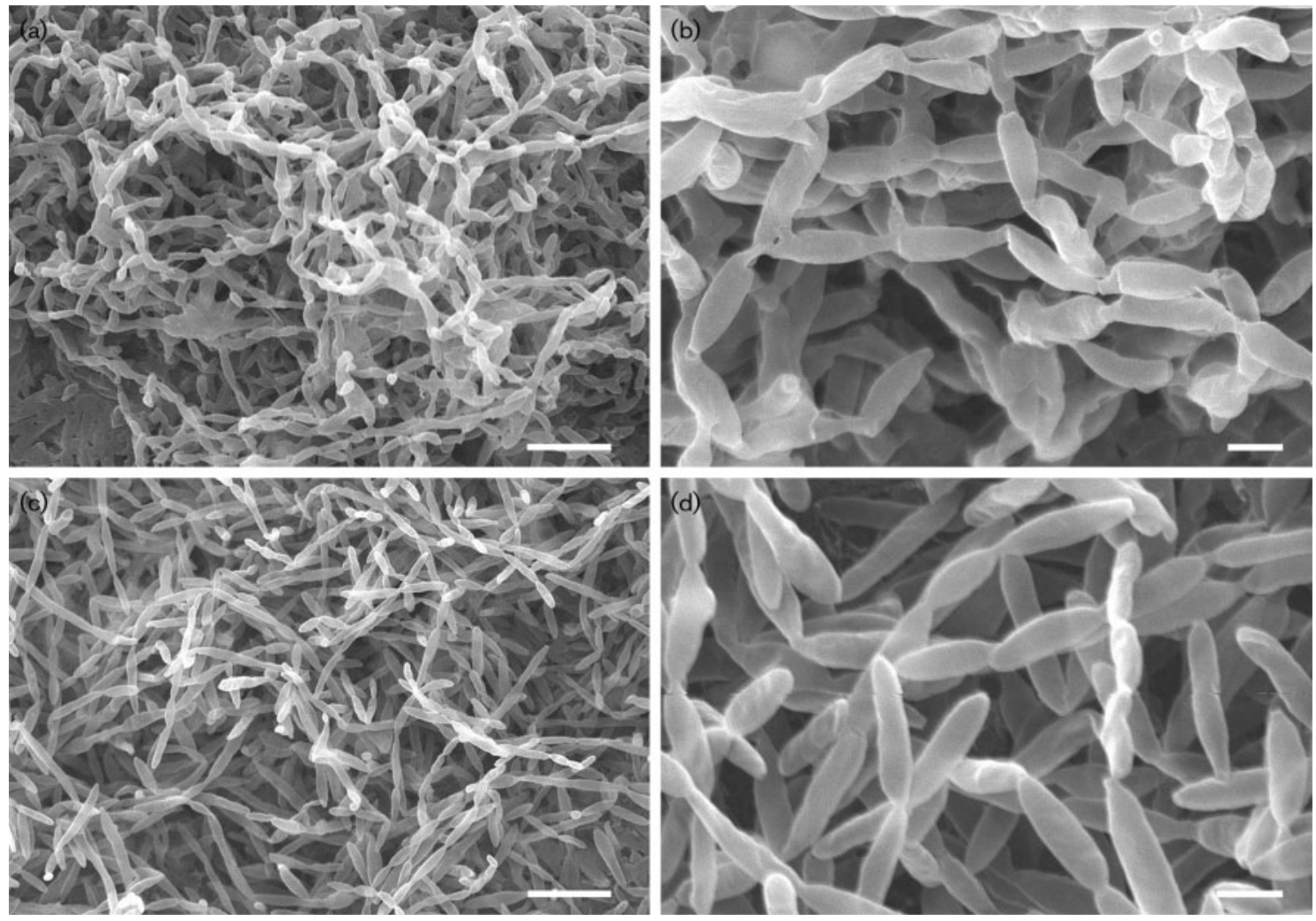

Fig. 1. Scanning electron micrographs of aerial mycelium of strains $M N 08-A 0270^{\top}$ and $M N 08-A 0297^{\top}$ grown on water agar medium for 28 days at $28{ }^{\circ} \mathrm{C}$. (a, c) Abundant zigzag-shaped aerial hyphae with developing branches of strains MN08-A0270' (a) and MN08-A0297 ${ }^{\top}$ (c). (b, d) Chains of long, smooth-walled spores of strains MN08-A0270 ${ }^{\top}$ (b) and MN08-A0297 (d) and elongation of hyphae by acropetal budding. Bars, $5 \mu \mathrm{m}(\mathrm{a}, \mathrm{c})$ and $1 \mu \mathrm{m}(\mathrm{b}, \mathrm{d})$.

Sequence analysis was performed with an ABI Prism BigDye Terminator cycle sequencing kit (PE Applied Biosystems) and an automatic DNA sequencer (model 3130 Genetic Analyzer; PE Applied Biosystems). BLAST analysis (Altschul et al., 1990) was used to compare the nearly complete $16 \mathrm{~S}$ rRNA gene sequences of strains

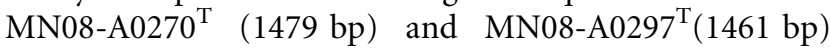
with sequences from the NCBI nucleotide database. Sequence alignments were generated using CLUSTAL_X (Thompson et al., 1997) with corresponding sequences (available in DDBJ/EMBL/GenBank) from the type strains of all Pseudonocardia species. Evolutionary distance matrices (Kimura's two-parameter model) were calculated and phylogenetic trees were inferred using the neighbourjoining method in CLUSTAL_X, the minimum-evolution (Rzhetsky \& Nei, 1992), maximum-parsimony (Eck \& Dayhoff, 1966) and neighbour-joining (Saitou \& Nei, 1987) tree-making algorithms in MEGA 4 (Tamura et al., 2007) and the maximum-likelihood method using the NUCML program in MOLPHY (Adachi \& Hasegawa, 1995; Hasegawa et al., 1985; Mori et al., 2003). Alignment gaps and ambiguous bases were removed prior to phylogenetic analyses by using BioEdit version 7.0.5.3 (Hall, 1999). Stability of the resultant tree topologies was evaluated by bootstrap analysis (Felsenstein, 1985) based on the neighbour-joining dataset of 1000 resamplings using CLUSTAL_X and MEGA 4. DNA G+C contents were determined by HPLC as described by Mesbah et al. (1989). DNA-DNA hybridization between strain MN08$\mathrm{A} 0297^{\mathrm{T}}$ and its closest phylogenetic neighbours was carried out by using the method described by Ezaki et al. (1989).

A phylogenetic tree was constructed according to the neighbour-joining algorithm based on 16S rRNA gene sequence data from strain MN08-A0297 ${ }^{\mathrm{T}}$ and corresponding sequences from type strains of the genus Pseudonocardia as well as Kutzneria kofuensis NRRL B$24061^{\mathrm{T}}$ (Fig. 1). The tree topology, supported by high bootstrap values, clearly separated strain MN08-A0297 within the genus Pseudonocardia. It is evident from the phylogenetic tree that strain MN08-A0297 ${ }^{\mathrm{T}}$ formed a strong cluster with $P$. thermophila ATCC $19285^{\mathrm{T}}$ with $97 \%$ bootstrap support; the 16S rRNA gene sequence similarity was $97.1 \%$. The $16 \mathrm{~S}$ rRNA gene sequence similarity of strain MN08-A0297 ${ }^{\mathrm{T}}$ to other members of the genus Pseudonocardia, such as Pseudonocardia aurantiaca AS $4.1537^{\mathrm{T}}(96.8 \%)$, P. chloroethenivorans SL- $1^{\mathrm{T}}$ $(96.6 \%)$ and P. alaniniphila YIM $16303^{\mathrm{T}}(96.5 \%)$, was less 
Table 2. Differential physiological and biochemical characteristics of strains $M N 08-A 0270^{\top}$ and MN08-A0297 ${ }^{\top}$ and $P$. thermophila NBRC $15559^{\top}$

All data were obtained in this study. + , Positive; \pm , weakly positive; - , negative.

\begin{tabular}{|c|c|c|c|}
\hline Characteristic & MN08-A0270 $^{\mathrm{T}}$ & $\mathrm{MN08-A0297}^{\mathrm{T}}$ & P. thermophila NBRC $15559^{\mathrm{T}}$ \\
\hline \multicolumn{4}{|l|}{ Growth temperature $\left({ }^{\circ} \mathrm{C}\right)$} \\
\hline Range & $15-30$ & $15-30$ & $25-50$ \\
\hline Optimum & $25-30$ & $25-30$ & $30-45$ \\
\hline \multicolumn{4}{|l|}{ Growth pH } \\
\hline Range & $4-11$ & $5-11$ & $6-9$ \\
\hline Optimum & $5-7$ & $6-8$ & $7-8$ \\
\hline \multicolumn{4}{|l|}{$\mathrm{NaCl}$ tolerance $(\% \mathrm{w} / \mathrm{v})$} \\
\hline Range & $0-2$ & $0-3$ & $0-3$ \\
\hline Optimum & $0-1$ & $0-2$ & $0-2$ \\
\hline Calcium malate assimilation & - & + & - \\
\hline Urea hydrolysis & + & + & \pm \\
\hline Starch hydrolysis & - & + & - \\
\hline \multicolumn{4}{|l|}{ Degradation of: } \\
\hline Arbutin & + & + & - \\
\hline Hypoxanthine & - & + & - \\
\hline Tyrosine & - & + & + (black pigment) \\
\hline Tween 80 & - & - & + \\
\hline Nitrate reduction & - & - & + \\
\hline Catalase & - & - & + \\
\hline \multicolumn{4}{|l|}{ API ZYM enzyme assay } \\
\hline Alkaline phosphatase & - & + & \pm \\
\hline Valine arylamidase & \pm & + & + \\
\hline Cystine arylamidase & \pm & + & \pm \\
\hline Trypsin & - & \pm & + \\
\hline$\alpha$-Chymotrypsin & - & \pm & - \\
\hline Acid phosphatase & - & + & + \\
\hline$\alpha$-Galactosidase & - & + & - \\
\hline$\beta$-Galactosidase & - & \pm & - \\
\hline$\beta$-Glucuronidase & - & \pm & - \\
\hline$\beta$-Glucosidase & + & + & - \\
\hline$\alpha$-Mannosidase & - & + & - \\
\hline
\end{tabular}

than $97.0 \%$. In this study, to establish the precise taxonomic position of strain MN08-A0297 ${ }^{\mathrm{T}}$, DNA-DNA hybridization studies were performed. The DNA-DNA relatedness between strain $\mathrm{MN} 08-\mathrm{A} 0297^{\mathrm{T}}$ and $P$. thermophila NBRC $15559^{\mathrm{T}}$ was $11.0 \%$ with both strains (means of three almost equal results). When the recommendation of a threshold value of $70 \%$ DNA-DNA relatedness for the definition of bacterial species (Stackebrandt \& Goebel, 1994) is considered, this result suggests strongly that strain MN08-A0297 ${ }^{\mathrm{T}}$ represents a novel species of the genus Pseudonocardia. Thus, based on the differential physiological and biochemical properties presented in this study (Tables 1 and 2) and DNA-DNA relatedness, strain MN08$\mathrm{A} 0297^{\mathrm{T}}$ can be considered to represent a novel member of the genus Pseudonocardia.

It is also evident from the phylogenetic tree that strain MN08-A0270 ${ }^{\mathrm{T}}$ formed a close cluster with Pseudonocardia halophobica DSM 43089 ${ }^{\mathrm{T}}(96.4 \%), P$. ailaonensis YIM $45505^{\mathrm{T}}(96.4 \%)$ and P. oroxyli $\mathrm{D} 10^{\mathrm{T}}(96.2 \%)$, but did not form definite clusters with the most closely related strains,
P. yunnanensis NBRC $15681^{\mathrm{T}}(97.3 \%)$ and P. alaniniphila YIM $16303^{\mathrm{T}}$ (97.2\%). Further, strain MN08-A0270 ${ }^{\mathrm{T}}$ could be differentiated from the phylogenetically closely related type strains $P$. halophobica DSM $43089^{\mathrm{T}}, P$. ailaonensis YIM $45505^{\mathrm{T}}$ and $P$. oroxyli $\mathrm{D} 10^{\mathrm{T}}$ by the presence of different proportions of fatty acid components. The complete cellular fatty acid profiles of strain MN08-A0270,$P$. halophobica IMSNU $21327^{\mathrm{T}}$, $P$. ailaonensis YIM $45505^{\mathrm{T}}$ and P. oroxyli DSM $44984^{\mathrm{T}}$ are shown in Table 3. Strain MN08$\mathrm{A} 0270^{\mathrm{T}}$ was also readily differentiated from its closest relatives $P$. yunnanensis NBRC $15681^{\mathrm{T}}$, P. alaniniphila YIM $16303^{\mathrm{T}}$, P. halophobica DSM $43089^{\mathrm{T}}$, P. ailaonensis YIM $45505^{\mathrm{T}}$ and $P$. oroxyli $\mathrm{D} 10^{\mathrm{T}}$ on the basis of physiological and biochemical properties (Table 4). Taking this into consideration, we conclude that the differences between strain MN08-A0270 ${ }^{\mathrm{T}}$ and phylogenetically closely related Pseudonocardia type strains are large enough to exclude the assignment of the strain to any recognized Pseudonocardia species. Therefore, based on its phenotypic and genotypic properties, strain $\mathrm{MN} 08-\mathrm{A} 0270^{\mathrm{T}}$ is also considered to represent a novel species of the genus Pseudonocardia. 
Table 3. Fatty acid compositions of strains $\mathrm{MNO8}-\mathrm{A} 0270^{\top}$ and MN08-A0297 ${ }^{\top}$ and closely related Pseudonocardia type strains

Strains: $1, \mathrm{MN} 08-\mathrm{A} 0297^{\mathrm{T}} ; 2, \mathrm{MN} 08-\mathrm{A} 0270^{\mathrm{T}} ; 3$, P. thermophila NBRC $15559^{\mathrm{T}}$; 4, P. halophobica IMSNU $21327^{\mathrm{T}}$; 5, P. ailaonensis YIM $45505^{\mathrm{T}} ; 6$, P. oroxyli DSM $44984^{\mathrm{T}}$. Values are percentages of total fatty acids. Data were obtained in this study or taken from Qin et al. (2008) (P. halophobica IMSNU $21327^{\mathrm{T}}$, P. ailaonensis YIM $45505^{\mathrm{T}}$ and $P$. oroxyli DSM $44984^{\mathrm{T}}$ ). - , Not reported or absent.

\begin{tabular}{|c|c|c|c|c|c|c|}
\hline Fatty acid composition & 1 & 2 & 3 & 4 & 5 & 6 \\
\hline \multicolumn{7}{|l|}{ Saturated straight-chain } \\
\hline $\mathrm{C}_{14: 0}$ & - & - & - & 0.6 & 1.8 & - \\
\hline $\mathrm{C}_{15: 0}$ & 0.4 & - & 0.3 & 2.0 & - & - \\
\hline $\mathrm{C}_{16: 0}$ & 0.9 & 0.7 & 2.7 & 6.3 & 8.4 & 1.7 \\
\hline $\mathrm{C}_{17: 0}$ & 0.8 & - & 1.3 & 1.0 & - & - \\
\hline $\mathrm{C}_{18: 0}$ & - & - & 1.2 & - & - & - \\
\hline \multicolumn{7}{|l|}{ Saturated branched } \\
\hline iso- $\mathrm{C}_{14: 0}$ & 0.6 & 5.7 & 0.4 & 0.7 & 1.6 & 2.5 \\
\hline iso- $\mathrm{C}_{15: 0}$ & 4.0 & 3.2 & 5.0 & 4.6 & 7.8 & 2.9 \\
\hline anteiso- $\mathrm{C}_{15: 0}$ & - & - & 0.4 & 1.3 & 1.6 & - \\
\hline iso- $\mathrm{C}_{16: 0}$ & 16.0 & 27.8 & 26.4 & 34.8 & 35.5 & 49.5 \\
\hline 9-Methyl $C_{16: 0}$ & - & - & 11.8 & - & - & - \\
\hline 10-Methyl $C_{16: 0}$ & 11.4 & 6.2 & - & 7.4 & 9.0 & 10.5 \\
\hline 10-Methyl $C_{17: 0}$ & 8.8 & 1.1 & 1.0 & 1.2 & - & - \\
\hline iso- $\mathrm{C}_{16: 0} 2-\mathrm{OH}$ & 21.0 & 12.0 & 1.9 & 3.6 & 10.8 & 11.5 \\
\hline iso- $\mathrm{C}_{17: 0}$ & 1.6 & 0.9 & 23.3 & 2.6 & 4.7 & 0.8 \\
\hline anteiso- $\mathrm{C}_{17: 0}$ & 1.5 & - & 12.3 & 6.6 & - & - \\
\hline iso- $\mathrm{C}_{17: 0} 2-\mathrm{OH}$ & - & - & 2.0 & - & - & - \\
\hline anteiso- $\mathrm{C}_{17: 0} 2-\mathrm{OH}$ & 0.8 & - & 1.2 & - & 1.4 & - \\
\hline iso- $\mathrm{C}_{18: 0}$ & 0.7 & - & 2.8 & - & - & - \\
\hline 10-Methyl $C_{18: 0}$ & 0.4 & - & - & - & - & - \\
\hline \multicolumn{7}{|l|}{ Unsaturated } \\
\hline $\mathrm{C}_{15: 1} \mathrm{~B}$ & 0.5 & - & - & 1.5 & - & - \\
\hline iso- $\mathrm{C}_{16: 1} \mathrm{H}$ & 18.7 & 18.5 & 0.5 & 5.9 & 6.9 & 13.0 \\
\hline $\mathrm{C}_{16: 1} 2-\mathrm{OH}$ & 2.2 & 0.6 & 2.1 & - & - & - \\
\hline $\mathrm{C}_{16: 1}$ cis 9 & - & - & 1.6 & 14.5 & 5.2 & 4.3 \\
\hline anteiso- $\mathrm{C}_{17: 1} \mathrm{C}$ & 0.5 & - & 0.5 & 0.9 & - & - \\
\hline $\mathrm{C}_{17: 1}$ cis 9 & - & - & 0.8 & 3.5 & - & - \\
\hline $\mathrm{C}_{18: 1}$ cis 9 & - & - & 0.5 & - & - & - \\
\hline Unknown 16.048 & 9.0 & 23.0 & - & - & - & - \\
\hline Total unidentified & - & - & - & 0.4 & - & 2.2 \\
\hline
\end{tabular}

It is evident from Fig. 2 that strains $\mathrm{MN} 08-\mathrm{A} 0270^{\mathrm{T}}$ and MN08-A0297 ${ }^{\mathrm{T}}$ formed two distinct clades in the genus Pseudonocardia 16S rRNA gene tree with the closely related type strains $P$. yunnanensis IFO $15681^{\mathrm{T}}(97.3 \%)$ and $P$. thermophila ATCC $19285^{\mathrm{T}}$ (97.1\%). The binary similarity of the $16 \mathrm{~S}$ rRNA gene sequences of strains MN08-A0270 ${ }^{\mathrm{T}}$ and MN08-A0297 ${ }^{\mathrm{T}}$ was $97.0 \%$; this association was supported by the maximum-likelihood (Felsenstein, 1981), minimumevolution (Rzhetsky \& Nei, 1992), maximum-parsimony (Eck \& Dayhoff, 1966) and neighbour-joining (Saitou \& Nei, 1987) tree-making algorithms (Fig. 2). Therefore, strains MN08-A0270 ${ }^{\mathrm{T}}$ and MN08-A0297 ${ }^{\mathrm{T}}$ were different from closely related type strains of Pseudonocardia species. Both strains had DNA G + C contents of $73.0 \mathrm{~mol} \%$.
Table 4. Differential physiological and biochemical characteristics of strain MN08-A0270 ${ }^{\top}$ and closely related Pseudonocardia type strains

Strains: 1, MN08-A0270 $; 2$, P. yunnanensis NBRC $15681^{\mathrm{T}} ; 3, P$. alaniniphila YIM $16303^{\mathrm{T}}$ (data in columns 2-3 from Sakiyama et al., 2010; Gu et al., 2006; Huang et al., 2002); 4, P. halophobica IMSNU $21327^{\mathrm{T}} ; 5$, P. ailaonensis YIM 45505 ${ }^{\mathrm{T}} ; 6$, P. oroxyli DSM $44984^{\mathrm{T}}$ (data in columns 4-6 from Qin et al., 2008). +, Positive; -, negative; \pm , weakly positive; $\mathrm{ND}$, not done.

\begin{tabular}{|c|c|c|c|c|c|c|}
\hline Character & 1 & 2 & 3 & 4 & 5 & 6 \\
\hline \multicolumn{7}{|l|}{ Decomposition of: } \\
\hline Urea & + & - & - & - & + & - \\
\hline Hypoxanthine & - & + & + & \pm & + & + \\
\hline Adenine & - & - & - & \pm & - & + \\
\hline Xanthine & $\mathrm{ND}$ & - & - & + & \pm & + \\
\hline Tyrosine & - & - & - & \pm & + & + \\
\hline \multicolumn{7}{|c|}{ Growth on $\mathrm{NaCl}$ at: } \\
\hline $3 \%(\mathrm{w} / \mathrm{v})$ & - & - & - & + & + & + \\
\hline $5 \%(\mathrm{w} / \mathrm{v})$ & - & - & - & \pm & + & + \\
\hline $7 \%(w / v)$ & - & - & - & \pm & - & \pm \\
\hline
\end{tabular}

Strains MN08-A0270 ${ }^{\mathrm{T}}$ and MN08-A0297 ${ }^{\mathrm{T}}$ were examined for key chemical markers to determine whether they had a chemotaxonomic profile consistent with their classification in the genus Pseudonocardia. Biomass for quantitative fatty acid analysis was collected from fresh agar plates after 2 weeks at $28{ }^{\circ} \mathrm{C}$. Cellular fatty acid profiles were determined by GLC (MIDI) using the standard protocol (Sasser, 1990). Strains MN08-A0270 ${ }^{\mathrm{T}}$ and MN08-A0297 ${ }^{\mathrm{T}}$ contained large amounts of iso-branched saturated and unsaturated branched fatty acids in comparison with other species of the genus Pseudonocardia, predominantly iso$\mathrm{C}_{16: 0}$, iso- $\mathrm{C}_{16: 0} 2-\mathrm{OH}, 10$-methyl $\mathrm{C}_{16: 0}$, iso- $\mathrm{C}_{16: 1} \mathrm{H}$ and a unknown fatty acid. Further, strains $\mathrm{MN} 08-\mathrm{A}_{02} 270^{\mathrm{T}}$ and MN08-A0297 ${ }^{\mathrm{T}}$ could be differentiated from each other by their complete cellular fatty acid profiles (Table 3 ).

Biomass for analyses of other chemical markers was harvested using centrifugation of cell mass from cultures grown for 3 weeks in yeast extract-glucose (YG) broth $(10 \mathrm{~g}$ yeast extract and 10 g glucose $\left.1^{-1}, \mathrm{pH} 7.0\right)$ grown at $28{ }^{\circ} \mathrm{C}$ in a shaker incubator. The harvested cell mass was washed twice with sterile distilled water and freeze-dried. Menaquinone analyses were carried out by the method of Minnikin et al. (1984). Quinones were extracted from $100 \mathrm{mg}$ freeze-dried cell material using chloroform/methanol and separated by TLC on silica gel, removed from the plate and further analysed by HPLC. The menaquinones were MK- $8\left(\mathrm{H}_{4}\right)$ (accounting for $84 \%$ of the total), MK- $8\left(\mathrm{H}_{2}\right)(12 \%)$ and MK- $8\left(\mathrm{H}_{0}\right)(4 \%)$ for strain MN08-A0270 ${ }^{\mathrm{T}}$ and MK- $8\left(\mathrm{H}_{4}\right)$ $(92 \%)$, MK-8 $\left(\mathrm{H}_{2}\right)(4 \%)$, MK-8 $\left(\mathrm{H}_{0}\right)(2 \%)$ and MK-8 $\left(\mathrm{H}_{6}\right)$ $(0.8 \%)$ for strain MN08-A0297 ${ }^{\mathrm{T}}$. Whole-cell sugars were analysed as described by Staneck \& Roberts (1974). The diaminopimelic acid isomer in the peptidoglycan was analysed as described by Nozawa et al. (2007). Mycolic acids were analysed as described previously (Tamura et al., 1994). 


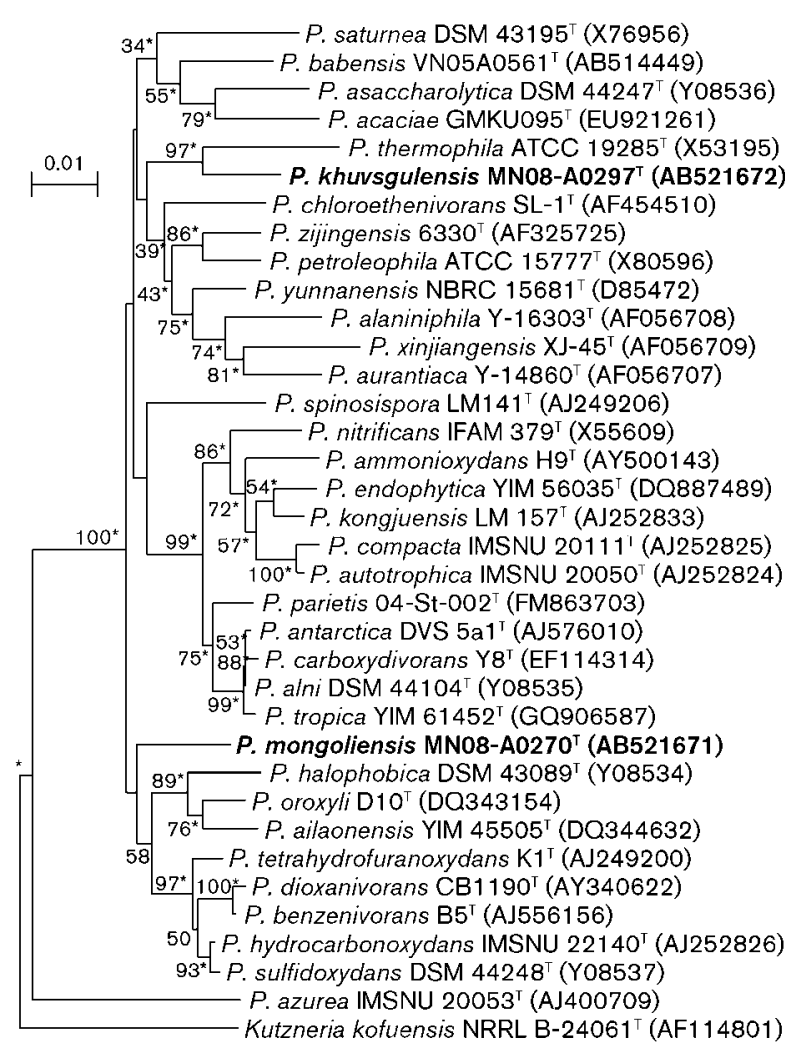

Fig. 2. Phylogenetic tree constructed by the neighbour-joining method (Saitou \& Nei, 1987) using almost-complete 16S rRNA gene sequences, showing relationships of strains $M N 08-A 0270^{\top}$ and MN08-A0297 ${ }^{\top}$ with type strains of all Pseudonocardia species. Numbers on branches indicate percentage bootstrap values determined for 1000 replicates (only values above $50 \%$ are indicated). Bar, $0.01 K_{\text {nuc. Asterisks }}\left(^{*}\right)$ indicate branches of the tree that were also recovered using the maximum-likelihood tree-making algorithm.

The complete chemotaxonomic profiles of strains MN08$\mathrm{A} 0270^{\mathrm{T}}$ and $\mathrm{MN} 08-\mathrm{A} 0297^{\mathrm{T}}$ determined in this study can be found in the species descriptions.

Physiological and chemotaxonomic analyses indicated that strains MN08-A0270 ${ }^{\mathrm{T}}$ and MN08-A0297 ${ }^{\mathrm{T}}$ belong to the genus Pseudonocardia; 16S rRNA gene sequence analyses indicated that they represent two novel species. Phenotypic characters and fatty acid analysis are also consistent with novel species status for strains MN08-A0270 ${ }^{\mathrm{T}}$ and MN08$\mathrm{A} 0297^{\mathrm{T}}$. Therefore, it is concluded that strains MN08$\mathrm{A} 0270^{\mathrm{T}}$ and MN08-A0297 ${ }^{\mathrm{T}}$ represents two novel species within the genus Pseudonocardia, for which the names Pseudonocardia mongoliensis sp. nov. and Pseudonocardia khuvsgulensis sp. nov. are proposed.

\section{Description of Pseudonocardia mongoliensis sp. nov.}

Pseudonocardia mongoliensis (mon.go.li.en'sis. N.L. fem. adj. mongoliensis of or belonging to Mongolia, referring to the isolation of the type strain from soil of Mongolia).
Aerobic, Gram-stain-positive. Cells grow well on Bennett's, yeast-starch and ISP 2 agar at $28{ }^{\circ} \mathrm{C}$, forming welldeveloped, extensively branched and non-fragmented substrate hyphae. Extensive acropetal budding of the white aerial hyphae and the formation of blastospores are observed. Very scanty aerial hyphae are formed, only on the surface of water agar. The substrate mycelium is light to moderate yellowish brown to pale yellow on different agar media. Optimal growth at $25-30{ }^{\circ} \mathrm{C}$; no growth at $37{ }^{\circ} \mathrm{C}$. Grows at pH $4-11$ and tolerates up to $2 \% \mathrm{NaCl}$. Catalase is not produced, nitrate is not reduced and gelatin, starch and Tweens 20 and 80 are not hydrolysed. Urea is hydrolysed. Arbutin is decomposed but casein, tyrosine, calcium malate, adenine and hypoxanthine are not. According to the API ZYM enzyme assay, positive for esterase $\left(\mathrm{C}_{4}\right)$, esterase lipase $\left(\mathrm{C}_{8}\right)$, leucine arylamidase, $\alpha$-glucosidase and $\beta$-glucosidase, weakly positive for lipase $\left(\mathrm{C}_{14}\right)$, valine arylamidase, cystine arylamidase, naphthol-AS-BI-phosphohydrolase and negative for alkaline phosphatase, trypsin, $\alpha$-chymotrypsin, acid phosphatase, $\alpha$-galactosidase, $\beta$-galactosidase, $\beta$-glucuronidase, $N$-acetyl- $\beta$-glucosaminidase, $\alpha$-fucosidase and $\alpha$-mannosidase. According to the API Coryne enzyme assay, positive for pyrazinamidase, alkaline phosphatase, $\alpha$-glucosidase, $\beta$-glucosidase, urease and hydrolysis of gelatin, weakly positive for utilization of D-glucose, D-ribose, D-xylose, D-mannitol, maltose and sucrose and negative for nitrate reduction, pyrrolidonyl arylamidase, $\beta$-glucuronidase, $\beta$-galactosidase, $N$-acetyl- $\beta$ glucosaminidase and catalase and utilization of lactose and glycogen. Peptidoglycan contains meso-diaminopimelic acid; diagnostic sugars are galactose, ribose, glucose, arabinose, mannose and rhamnose (trace). Mycolic acids are absent. The menaquinone system consists of MK$8\left(\mathrm{H}_{4}\right)$, MK- $8\left(\mathrm{H}_{2}\right)$ and MK- $8\left(\mathrm{H}_{0}\right)$. Major fatty acid methyl esters are iso- $\mathrm{C}_{16: 0}$, unknown ECL 16.05, iso- $\mathrm{C}_{16: 1} \mathrm{H}$ and iso- $\mathrm{C}_{16: 0} 2-\mathrm{OH}$. The detailed fatty acid profile of the type strain is given in Table 3. The $\mathrm{G}+\mathrm{C}$ content of the DNA of the type strain is $73.0 \mathrm{~mol} \%$.

The type strain, MN08-A0270 ${ }^{\mathrm{T}}\left(=\mathrm{NBRC} 105885^{\mathrm{T}}=\mathrm{VTCC}\right.$ D9- $25^{\mathrm{T}}$ ), was isolated from soil of Khuvsgul Lake, Khuvsgul province, Mongolia.

\section{Description of Pseudonocardia khuvsgulensis sp. nov.}

Pseudonocardia khuvsgulensis (khuvs.gul.en'sis. N.L. fem. adj. khuvsgulensis of or belonging to Khuvsgul, referring to the isolation of the type strain from soil of Khuvsgul Lake, Khuvsgul province, Mongolia).

Aerobic, non-motile, non-endospore-forming, Gramstain-positive actinomycete that forms extensively branched substrate and aerial mycelia that carry smoothsurfaced, rod-shaped spores. Extensive acropetal budding of the aerial hyphae and the formation of blastospores are observed. Good growth occurs on Bennett's, YS, ISP 2, ISP 4, ISP 5, ISP 6 and ISP 7 agar media at $28{ }^{\circ} \mathrm{C}$. Forms white aerial mycelium and pale yellow to moderate yellowish 
brown substrate mycelium on the media tested. No diffusible pigment is produced. Grows at $15-30{ }^{\circ} \mathrm{C}$ (optimum $25-30{ }^{\circ} \mathrm{C}$ ), at $\mathrm{pH}$ 5.0-11.0 (optimum $\mathrm{pH} 6.0$ 6.8 ) and at 0-3.0\% (w/v) $\mathrm{NaCl}$ (optimum 0-2.0\%). Positive for urease and decomposition of hypoxanthine, tyrosine, calcium malate and arbutin, but negative for catalase, nitrate reduction, gelatin liquefaction, hydrolysis of starch and Tweens 20 and 80 and decomposition of casein and adenine. According to the API ZYM enzyme assay, positive for alkaline phosphatase, esterase $\left(\mathrm{C}_{4}\right)$, esterase lipase $\left(\mathrm{C}_{8}\right)$, leucine arylamidase, valine arylamidase, cystine arylamidase, acid phosphatase, $\alpha$-glucosidase, $\beta$-glucosidase and $\alpha$-mannosidase, weakly positive for lipase $\left(\mathrm{C}_{14}\right)$, trypsin, $\alpha$-galactosidase, $\alpha$-chymotrypsin, naphthol-AS-BI-phosphohydrolase, $\beta$-galactosidase and $\beta$-glucuronidase and negative for $N$-acetyl- $\beta$-glucosaminidase and $\alpha$-fucosidase. According to the API Coryne enzyme assay, positive for pyrazinamidase, pyrrolidonyl arylamidase, alkaline phosphatase, $\beta$-galactosidase, $\alpha$-glucosidase, $N$-acetyl- $\beta$-glucosaminidase, $\beta$-glucosidase and urease and hydrolysis of gelatin and negative for catalase, nitrate reduction and $\beta$-glucuronidase. The cell wall contains meso-diaminopimelic acid. The whole-cell sugar pattern consists of galactose, glucose, arabinose, ribose, mannose and rhamnose (trace) (type IV cell wall). Mycolic acids are absent. MK- $8\left(\mathrm{H}_{4}\right)$ is the predominant menaquinone. The major fatty acid methyl esters are iso- $\mathrm{C}_{16: 0} 2-$ $\mathrm{OH}$, iso- $\mathrm{C}_{16: 1} \mathrm{H}$, iso- $\mathrm{C}_{16: 0}$ and 10-methyl $\mathrm{C}_{16: 0}$. The DNA $\mathrm{G}+\mathrm{C}$ content of the type strain is $73.0 \mathrm{~mol} \%$.

The type strain, MN08-A0297 ${ }^{\mathrm{T}}\left(=\mathrm{NBRC} 105886^{\mathrm{T}}=\mathrm{VTCC}\right.$ D9-26 ${ }^{\mathrm{T}}$ ), was isolated from soil of Khuvsgul Lake, Khuvsgul province, Mongolia.

\section{Acknowledgements}

We would like to thank the Research Center for Female Scientific and Medical Colleges at King Saud University, Riyadh, for their cooperation. We are grateful to Dr Jean Euzéby for his help with nomenclature. This work was conducted under a Joint Research Project between the Department of Biotechnology, NITE, Japan, and the Institute of Biology, Mongolian Academy of Sciences, Mongolia. We acknowledge Dr Tomohiko Tamura for scientific advice and Ms Yayoi Sakiyama for assistance with chemotaxonomic analyses.

\section{References}

Adachi, J. \& Hasegawa, M. (1995). Improved dating of the human/ chimpanzee separation in the mitochondrial DNA tree: heterogeneity among amino acid sites. J Mol Evol 40, 622-628.

Akimov, V. N., Evtushenko, L. I. \& Dobritsa, S. V. (1989). Pseudoamycolata halophobica gen. nov., sp. nov. Int J Syst Bacteriol 39, 457-461.

Altschul, S. F., Gish, W., Miller, W., Myers, E. W. \& Lipman, D. J. (1990). Basic local alignment search tool. J Mol Biol 215, 403-410.

Ara, I., Yamamura, H., Tsetseg, B., Daram, D. \& Ando, K. (2010a). Luteipulveratus mongoliensis gen. nov., sp. nov., a new actinobacterial taxon in the family Dermacoccaceae. Int J Syst Evol Microbiol 60, 574579 .
Ara, I., Yamamura, H., Tsetseg, B., Daram, D. \& Ando, K. (2010b). Actinoplanes toevensis sp. nov. and Actinoplanes tereljensis sp. nov., isolated from Mongolian soil. Int J Syst Evol Microbiol 60, 919-927.

Chen, H.-H., Qin, S., Li, J., Zhang, Y.-Q., Xu, L.-H., Jiang, C.-L., Kim, C.-J. \& Li, W.-J. (2009). Pseudonocardia endophytica sp. nov., isolated from the pharmaceutical plant Lobelia clavata. Int J Syst Evol Microbiol 59, 559-563.

Duangmal, K., Thamchaipenet, A., Matsumoto, A. \& Takahashi, Y. (2009). Pseudonocardia acaciae sp. nov., isolated from roots of Acacia auriculiformis A. Cunn. ex Benth. Int J Syst Evol Microbiol 59, 14871491.

Eck, R. V. \& Dayhoff, M. O. (1966). Atlas of Protein Sequences and Structure. Silver Springs, MD: National Biomedical Research Foundation.

Evtushenko, L. I., Akimov, V. N., Dobritsa, S. V. \& Taptykova, S. D. (1989). A new species of actinomycete, Amycolata alni. Int J Syst Bacteriol 39, 72-77.

Ezaki, T., Hashimoto, Y. \& Yabuuchi, E. (1989). Fluorometric deoxyribonucleic acid-deoxyribonucleic acid hybridization in microdilution wells as an alternative to membrane filter hybridization in which radioisotopes are used to determine genetic relatedness among bacterial strains. Int J Syst Bacteriol 39, 224-229.

Felsenstein, J. (1981). Evolutionary trees from DNA sequences: a maximum likelihood approach. J Mol Evol 17, 368-376.

Felsenstein, J. (1985). Confidence limits on phylogenies: an approach using the bootstrap. Evolution 39, 783-791.

Gordon, R. E. \& Mihm, J. M. (1957). A comparative study of some strains received as nocardiae. J Bacteriol 73, 15-27.

Gordon, R. E., Barnett, D. A., Handerhan, J. E. \& Pang, C. H.-N. (1974). Nocardia coeliaca, Nocardia autotrophica, and the nocardin strain. Int J Syst Bacteriol 24, 54-63.

Gu, Q., Luo, H., Zheng, W., Liu, Z. \& Huang, Y. (2006). Pseudonocardia oroxyli sp. nov., a novel actinomycete isolated from surface-sterilized Oroxylum indicum root. Int J Syst Evol Microbiol 56, 2193-2197.

Hall, T. A. (1999). BioEdit: a user-friendly biological sequence alignment editor and analysis program for Windows 95/98/NT. Nucleic Acids Symp Ser 41, 95-98.

Hasegawa, M., Kishino, H. \& Yano, T. (1985). Dating of the humanape splitting by a molecular clock of mitochondrial DNA. J Mol Evol 22, 160-174.

Hayakawa, M. \& Nonomura, H. (1987). Humic acid-vitamin agar, a new medium for the selective isolation of soil actinomycetes. J Ferment Technol 65, 501-509.

Hayakawa, M., Otoguro, M., Takeuchi, T., Yamazaki, T. \& limura, Y. (2000). Application of a method incorporating differential centrifugation for selective isolation of motile actinomycetes in soil and plant litter. Antonie van Leeuwenhoek 78, 171-185.

Henssen, A. (1957). Beiträge zur Morphologie und Systematik der thermophilen Actinomyceten. Arch Mikrobiol 26, 373-414 (in German).

Henssen, A. \& Schäfer, D. (1971). Emended description of the genus Pseudonocardia Henssen and description of a new species Pseudonocardia spinosa Schäfer. Int J Syst Bacteriol 21, 29-34.

Huang, Y., Wang, L., Lu, Z., Hong, L., Liu, Z., Tan, G. Y. A. \& Goodfellow, M. (2002). Proposal to combine the genera Actinobispora and Pseudonocardia in an emended genus Pseudonocardia, and description of Pseudonocardia zijingensis sp. nov. Int J Syst Evol Microbiol 52, 977-982.

Humble, M. W., King, A. \& Phillips, I. (1977). API ZYM: a simple rapid system for the detection of bacterial enzymes. J Clin Pathol 30, 275277. 
Jiang, C., Xu, L., Yang, Y.-R., Guo, G.-Y., Ma, J. \& Liu, Y. (1991). Actinobispora, a new genus of the order Actinomycetales. Int J Syst Bacteriol 41, 526-528.

Kämpfer, P. \& Kroppenstedt, R. M. (2004). Pseudonocardia benzenivorans sp. nov. Int J Syst Evol Microbiol 54, 749-751.

Kämpfer, P., Kohlweyer, U., Thiemer, B. \& Andreesen, J. R. (2006). Pseudonocardia tetrahydrofuranoxydans sp. nov. Int J Syst Evol Microbiol 56, 1535-1538.

Kloos, W. E., Tornabene, T. G. \& Schleifer, K. H. (1974). Isolation and characterization of micrococci from human skin, including two new species: Micrococcus lylae and Micrococcus kristinae. Int J Syst Bacteriol 24, 79-101.

Kothe, H. W., Vobis, G., Kroppenstedt, R. M. \& Henssen, A. (1989). A taxonomic study of mycolateless, wall chemotype IV actinomycetes. Syst Appl Microbiol 12, 61-69.

Lechevalier, M. P. \& Lechevalier, H. A. (1980). The chemotaxonomy of actinomycetes. In Actinomycete Taxonomy (Special Publication 6), pp. 227-291. Arlington, VA: Society for Industrial Microbiology.

Lechevalier, M. P., Prauser, H., Labeda, D. P. \& Ruan, J. S. (1986). Two new genera of nocardioform actinomycetes: Amycolata gen. nov. and Amycolatopsis gen. nov. Int J Syst Bacteriol 36, 29-37.

Lee, S. D., Kim, E. S. \& Hah, Y. C. (2000). Phylogenetic analysis of the genera Pseudonocardia and Actinobispora based on $16 \mathrm{~S}$ ribosomal DNA sequences. FEMS Microbiol Lett 182, 125-129.

Lee, S. D., Kim, E. S., Min, K.-L., Lee, W. Y., Kang, S.-O. \& Hah, Y. C. (2001). Pseudonocardia kongjuensis sp. nov., isolated from a gold mine cave. Int J Syst Evol Microbiol 51, 1505-1510.

Lee, S. D., Kim, E. S., Kang, S.-O. \& Hah, Y. C. (2002). Pseudonocardia spinosispora sp. nov., isolated from Korean soil. Int J Syst Evol Microbiol 52, 1603-1608.

Lee, S.-B., Strand, S. E., Stensel, H. D. \& Herwig, R. P. (2004). Pseudonocardia chloroethenivorans sp. nov., a chloroethene-degrading actinomycete. Int J Syst Evol Microbiol 54, 131-139.

Liu, Z.-P., Wu, J.-F., Liu, Z. H. \& Liu, S.-J. (2006). Pseudonocardia ammonioxydans sp. nov., isolated from coastal sediment. Int J Syst Evol Microbiol 56, 555-558.

Mahendra, S. \& Alvarez-Cohen, L. (2005). Pseudonocardia dioxanivorans sp. nov., a novel actinomycete that grows on 1,4-dioxane. Int $J$ Syst Evol Microbiol 55, 593-598.

Marmur, J. (1961). A procedure for the isolation of deoxyribonucleic acid from microorganisms. J Mol Biol 3, 208-218.

McVeigh, H. P., Munro, J. \& Embley, T. M. (1994). The phylogenetic position of Pseudoamycolata halophobica (Akimov et al. 1989) and a proposal to reclassify it as Pseudonocardia halophobica. Int J Syst Bacteriol 44, 300-302.

Mesbah, M., Premachandran, U. \& Whitman, W. B. (1989). Precise measurement of the $\mathrm{G}+\mathrm{C}$ content of deoxyribonucleic acid by highperformance liquid chromatography. Int J Syst Bacteriol 39, 159167.

Minnikin, D. E., O'Donnell, A. G., Goodfellow, M., Alderson, G., Athalye, M., Schaal, A. \& Parlett, J. H. (1984). An integrated procedure for the extraction of bacterial isoprenoid quinones and polar lipids. J Microbiol Methods 2, 233-241.

Mori, K., Kim, H., Kakegawa, T. \& Hanada, S. (2003). A novel lineage of sulfate-reducing microorganisms: Thermodesulfobiaceae fam. nov., Thermodesulfobium narugense, gen. nov., sp. nov., a new thermophilic isolate from a hot spring. Extremophiles 7, 283-290.

Nozawa, Y., Sakai, N., Arai, K., Kawasaki, Y. \& Harada, K. (2007). Reliable and sensitive analysis of amino acids in the peptidoglycan of actinomycetes using the advanced Marfey's method. J Microbiol Methods 70, 306-311.
Park, S. W., Park, S. T., Lee, J. E. \& Kim, Y. M. (2008). Pseudonocardia carboxydivorans sp. nov., a carbon monoxide-oxidizing actinomycete, and an emended description of the genus Pseudonocardia. Int J Syst Evol Microbiol 58, 2475-2478.

Qin, S., Su, Y. Y., Zhang, Y. Q., Wang, H. B., Jiang, C. L., Xu, L. H. \& Li, W. J. (2008). Pseudonocardia ailaonensis sp. nov., isolated from soil in China. Int J Syst Evol Microbiol 58, 2086-2089.

Qin, S., Zhu, W. Y., Jiang, J. H., Klenk, H. P., Li, J., Zhao, G. Z., Xu, L. H. \& Li, W. J. (2010). Pseudonocardia tropica sp. nov., an endophytic actinomycete isolated from the stem of Maytenus austroyunnanensis. Int J Syst Evol Microbiol 60, 2524-2528.

Rayner, R. W. (1970). A Mycological Colour Chart. Kew, UK: Commonwealth Mycological Institute and British Mycological Society.

Reichert, K., Lipski, A., Pradella, S., Stackebrandt, E. \& Altendorf, K. (1998). Pseudonocardia asaccharolytica sp. nov. and Pseudonocardia sulfidoxydans sp. nov., two new dimethyl disulfide-degrading actinomycetes and emended description of the genus Pseudonocardia. Int J Syst Bacteriol 48, 441-449.

Rzhetsky, A. \& Nei, M. (1992). A simple method for estimating and testing minimum evolution trees. Mol Biol Evol 9, 945-967.

Saito, H. \& Miura, K. (1963). Preparation of transforming deoxyribonucleic acid by phenol treatment. Biochim Biophys Acta 72, 619-629.

Saitou, N. \& Nei, M. (1987). The neighbor-joining method: a new method for reconstructing phylogenetic trees. Mol Biol Evol 4, 406425.

Sakiyama, Y., Thao, N. K. N., Vinh, H. V., Giang, N. M., Miyadoh, S., Hop, D. V. \& Ando, K. (2010). Pseudonocardia babensis sp. nov., isolated from plant litter. Int J Syst Evol Microbiol 60, 2336-2340.

Sasser, M. (1990). Identification of bacteria by gas chromatography of cellular fatty acids, MIDI Technical Note 101. Newark, DE: MIDI Inc.

Schäfer, J., Busse, H.-J. \& Kämpfer, P. (2009). Pseudonocardia parietis sp. nov., from the indoor environment. Int J Syst Evol Microbiol 59, 2449-2452.

Shirling, E. B. \& Gottlieb, D. (1966). Methods for characterization of Streptomyces species. Int J Syst Bacteriol 16, 313-340.

Stackebrandt, E. \& Goebel, B. M. (1994). Taxonomic note: a place for DNA-DNA reassociation and $16 \mathrm{~S}$ rRNA sequence analysis in the present species definition in bacteriology. Int J Syst Bacteriol 44, 846849.

Staneck, J. L. \& Roberts, G. D. (1974). Simplified approach to identification of aerobic actinomycetes by thin-layer chromatography. Appl Microbiol 28, 226-231.

Takeuchi, M., Nishii, T. \& Yokota, A. (1992). Taxonomic significance of arabinose in the family Pseudonocardiaceae. Actinomycetologica 6, 79-90.

Tamura, T. \& Hatano, K. (2001). Phylogenetic analysis of the genus Actinoplanes and transfer of Actinoplanes minutisporangius Ruan et al. 1986 and 'Actinoplanes aurantiacus' to Cryptosporangium minutisporangium comb. nov. and Cryptosporangium aurantiacum sp. nov. Int $J$ Syst Evol Microbiol 51, 2119-2125.

Tamura, T., Nakagaito, Y., Nishii, T., Hasegawa, T., Stackebrandt, E. \& Yokota, A. (1994). A new genus of the order Actinomycetales, Couchioplanes gen. nov., with descriptions of Couchioplanes caeruleus (Horan and Brodsky 1986) comb. nov. and Couchioplanes caeruleus subsp. azureus subsp. nov. Int J Syst Bacteriol 44, 193-203.

Tamura, K., Dudley, J., Nei, M. \& Kumar, S. (2007). MEGA4: molecular evolutionary genetics analysis (MEGA) software version 4.0. Mol Biol Evol 24, 1596-1599.

Thompson, J. D., Gibson, T. J., Plewniak, F., Jeanmougin, F. \& Higgins, D. G. (1997). The CLUSTAL_X windows interface: flexible 
strategies for multiple sequence alignment aided by quality analysis tools. Nucleic Acids Res 25, 4876-4882.

Warwick, S., Bowen, T., McVeigh, H. P. \& Embley, T. M. (1994). A phylogenetic analysis of the family Pseudonocardiaceae and the genera Actinokineospora and Saccharothrix with 16S rRNA sequences and a proposal to combine the genera Amycolata and Pseudonocardia in an emended genus Pseudonocardia. Int J Syst Bacteriol 44, 293299. 